\title{
Вітамін D у генетичному аспекті та його роль за цүкрового діабету 1-го типу
}

\author{
Х.М. Щубелка ${ }^{1,2}$ \\ О.Т. Олексик ${ }^{1}$, \\ Т.Х. Олексик ${ }^{2}$, \\ Я.С. Гасинець ${ }^{1}$
}

\author{
' ДВНЗ «Ужгородський національний університет» \\ ${ }^{2}$ Oakland University
}

\begin{abstract}
Резюме. Вітамін D бере участь у різноманітних біологічних процесах, включаючи кістковий метаболізм, модуляцію імунної відповіді та регуляцію проліферації й диференціювання клітин. Дефіцит вітаміну D пов'язують із впливом на виникненням таких нескелетних захворювань, як цукровий діабет 1-го та 2-го типів, рак, серцевосудинні захворювання, що підтверджує плейотропний характер біологічної дії вітаміну D. Генетичні дослідження дають можливість вивчити генетично-молекулярні механізми впливу на циркулюючі рівні вітаміну D. Bapiaтивні ділянки ДНК, які часто трапляються в популяції — однонуклеотидні поліморфізми (ОНП, SNP) — можуть справляти вплив на метаболізм вітаміну D, а також модулювати дію вітаміну D у ході розвитку цукрового діабету 1-го типу. B огляді описано дані літератури щодо молекулярних механізмів дії вітаміну D, а також генів, які кодують ензими, відповідальні за його метаболізм, розглянуто генетичні дослідження різного типу в людських популяціях, метою яких було вивчення успадкування циркулюючих рівнів вітаміну D, вплив цих генетичних детермінант на розвиток цукрового діабету 1-го типу.
\end{abstract}

Ключові слова: вітамін D, цукровий діабет, генетичні дослідження.

\section{Біологічна роль вітаміну $\mathbf{D}$}

Вітамін D є важливим жиророзчинним вітаміном і стероїдним прогормоном, який відіграє ключову роль у мінералізації кісток. Він регулює концентрацію кальцію та фосфору в крові та позаклітинній рідині, а також забезпечує їх адекватну концентрацію для утворення гідроксиапатиту кальцію в кістковому матриксі. Дефіцит вітаміну D давно вивчений із точки зору причинності рахіту в дітей та остеомаляції в дорослих [1].

\footnotetext{
* Адреса для листування (Correspondence): ДВНЗ «Ужгородський національний університет», вул. Університетська, 14, м. Ужгород, 88000, Україна. E-mail:kshchubelka@oakland.edu

○ Х.М. Щубелка, О.Т. Олексик, Т.Х. Олексик, Я.С. Гасинець
}

На сьогодні ефекти вітаміну D пов’язують не лише з розладами опорно-рухового апарату, але й з такими поширеними захворюваннями, як рак, автоімунні, запальні, інфекційні, серцево-судинні хвороби та діабет [2-4].

Механізми фізіологічної дії вітаміну D

Вітамін D схожий за структурою зі стероїдними гормонами, і його дія реалізується також через ядерні рецептори, схожі на рецептори до гормонів щитоподібної, статевих і надниркових залоз. Його фізіологічні ефекти поширюються на широкий спектр тканин, оскільки рецептори до вітаміну D (VDR) є на багатьох типах клітин, включаючи імунні, а саме ден- 
Огляди

дритні клітини, макрофаги та Т-лімфоцити. Цей факт привертає особливу увагу, оскільки є багатообіцяючим із точки зору розробки нових терапевтичних підходів [5, 6].

Вітамін D існує у двох основних формах: вітамін $\mathrm{D}_{2}$ i вітамін $\mathrm{D}_{3}$. $\mathrm{D}_{2}$ (ергокальциферол) надходить до організму людини з харчовими продуктами, a $\mathrm{D}_{3}$ (холекальциферол) переважно утворюється ендогенно, шляхом фотохімічної реакції в шкірі з відповідних попередників. Унаслідок цієї реакції, під впливом ультрафіолетових променів 7-дегідрохолестерол (7ДХК, присутній у шкірі) перетворюється на превітамін $\mathrm{D}_{3} \mathrm{i}$ лише потім шляхом термічної ізомеризації - на вітамін $\mathrm{D}_{3}$ [7]. Подальше гідроксилювання вітаміну $\mathrm{D}_{3}$ відбувається в печінці завдяки ферменту 25-гідроксилазі (кодуючий ген CYP2R1), унаслідок чого утворюється 25 -гідроксивітамін $\mathrm{D}_{3}-25(\mathrm{OH}) \mathrm{D}_{3}$, кальцидіол. Саме він є головним циркулюючим метаболітом вітаміну D в організмі людини, за рівнем якого в сироватці крові визначається його статус. Наступне гідроксилювання $25(\mathrm{OH}) \mathrm{D}_{3}$ 1- $\alpha$-гідроксилазою (кодуючий ген $C Y P 27 B 1)^{3}$ у нирках або в екстраренальних клітинах, таких як макрофаги, приводить до утворення біологічно активного 1,25-дигідроксивітаміну $\mathrm{D}_{3}-1,25(\mathrm{OH})_{2} \mathrm{D}_{3}$, кальцитріолу [8]. $1,25(\mathrm{OH})_{2} \mathrm{D}_{3}$ здатен зв'язуватися 3 високою спорідненістю із VDR, який гетеродимеризується 3 ретиноїдним $\mathrm{X}$-рецептором альфа $(\mathrm{RXR} \alpha)$. Комплекс VDR-RXR $\alpha$ надалі переміщується в ядро клітин і зв'язується з елементами відповіді до вітаміну D (VDRE) у ділянках регуляторних елементів генів-мішеней вітаміну D. Вітамін D реалізує свій ефект на геном людини через залучення низки чинників транскрипції саме вцих ділянках, що регулює широкий спектр біологічних процесів, включаючи всмоктування кальцію та фосфатів, проліферацію та диференціацію клітин [9]. Широкий спектр фізіологічної дії вітаміну D пояснюється тим, що в геномі людини існують приблизно 2700 сайтів, що зв'язуються з VDR [9]. В організмі людини існує також зворотна регуляція рівня метаболітів вітаміну D: ензим 24-гідроксилаза (ген CYP24A1) обмежує надлишок концентрацій обох метаболітів - 25(OH)D $\mathrm{D}_{3}$ і $1,25(\mathrm{OH})_{2} \mathrm{D}_{3}$ шляхом метаболічної деградації (біоінактивації). У кровообігу більшість метаболітів вітаміну D транспортуються до різних органів-мішеней (тканин/кітин) у стані, зв'язаному з білкомтранспортером - вітамін D-зв'язуючим білком (DBP). Мегалін і кубілін (мультигігантні peцептори, що відповідають за ендоцитоз), відповідають за всмоктування $25(\mathrm{OH}) \mathrm{D}_{3}$, зв’язаного з DBP, усередину клітин [10]. Схематичне зображення метаболізму вітаміну D наведено на рис.

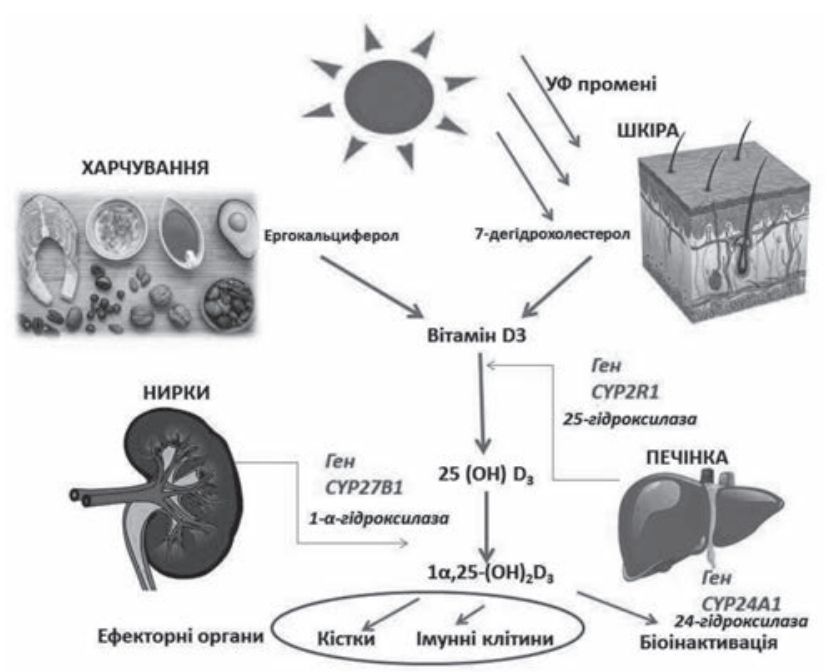

Рис. Метаболізм вітаміну D та основні гени, які його контролюють.

Генетичні детермінанти циркулюючих рівнів вітаміну D

Циркулюючі рівні вітаміну D залежать як від генетичних, так і від чинників довкілля. Так, успадковуваність циркулюючих рівнів вітаміну D було кількісно визначено в кількох дослідженнях близнюковим методом, вона коливається від <20\% до >85\% [11, 12]. У першому такому дослідженні взяли участь 1068 пар близнюків (384 монозиготних (М3) і 684 дизиготних (ДЗ), із них 98,3\% жінок європейського походження з когорти TwinsUK). Воно визначило успадковуваність 43\% (95\% ДІ 28$57 \%$ ) для $25(\mathrm{OH}) \mathrm{D}_{3} ; 65 \%$ (95\% ДІ 54-65\%) для $1,25(\mathrm{OH})_{2} \mathrm{D}_{3}$ і $62 \%$ (95\% ДI 56-66\%) для DВР. Це дослідження було також контрольованим щодо таких чинників впливу, як індекс маси тіла (IMT) і вік. Показники успадковуваності різнилися перед настанням менопаузи та після неї в жінок [11]. В іншому дослідженні було визначено успадковуваність на рівні 70\% (95\%

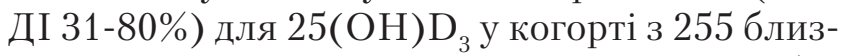
нюків чоловічої статі (155 МЗ і 100 Д3) із забиранням крові в зимовий період [12]. У когорті 
підлітків, середній вік яких становив 16 років, встановлено успадковуваність 86\% (95\% ДІ 61$94 \%)$ для 25(OH)D $\mathrm{D}_{3}(188$ дорослих пар близнюків (70 МЗ і 118 ДЗ)) [13].

Така варіативність результатів може бути поясненою такими чинниками, як стать, вік, сезон забирання крові [14], оскільки рівні вітаміну D різняться залежно від пори року, а також різним підходом до статистичної моделі та аналізу даних.

Результати попередніх досліджень шляхом вивчення можливих кандидатних генів (грунтуються на виборі однонуклеотидних поліморфізмів (ОНП) або генів, які вже описано в літературі як залучені до патогенезу хвороби) були невідповідними один одному, оскільки мали недостатню статистичну силу, включали різні етнічні групи та методи вимірювань. Вони фокусувалися в основному на генах, продукти експресії яких залучено у вищеописаний процес синтезу вітаміну D: CYP2R1 і CYP27B1 - два гени, які відповідають за гідроксилювання вітаміну D і його активацію; груповий компонент $(G C)$ - ген, що кодує DBP; $V D R$ - ген, який кодує рецептори до вітаміну D; CYP24A1 - ген, що відповідає за синтез гідроксилази, яка забезпечує біологічну інактивацію $1,25(\mathrm{OH})_{2} \mathrm{D}_{3}[15]$.

Перше генетичне дослідження методом повногеномного скринінгу (genome-wide association study - GWAS) асоціацій генетичних варіантів і циркулюючого рівня вітаміну 25(OH) $\mathrm{D}_{3}$ було проведено 2007 року. Оскільки воно було лімітованим за кількістю осіб і покриттям, було очікувано, що жоден ОНП не пройшов поріг значущості $\mathrm{p}=5 \times 10^{-8}$ для досліджень такого роду [16].

Пізніше було проведено набагато масштабніші GWAS-метааналізи, які включали велику кількість осіб європейського походження [17, 18]. Перший із них нараховував 4501 особу, відібрану з 6 когорт у першій фазі, та 2221 особу 33 когорт у другій фазі. Другий метааналіз, проведений консорціумом SUNLIGHT (Study of Underlying Genetic Determinants of Vitamin D and Highly Related Traits), згрупував дані з 15 когорт, які разом налічували 33996 індивідуумів. Обидва дослідження підтвердили сильну асоціацію трьох ОНП із циркулюючим рівнем вітаміну $\mathrm{D}$ у таких генах: GC (ОНП: rs2282679, $\left.\mathrm{p}=1,9 \times 10^{-109}\right)$, DHCR7/
NADSYN1 (ОНП: rs12785878, $\mathrm{p}=2,1 \times 10^{-27}$ ), CYP2R1 (ОНП: rs10741657, $\mathrm{p}=3,3 \times 10^{-20}$ ); додатково, SUNLIGHT мета-GWAS показав значущу асоціацію локусу CYP24A1 (ОНП: rs17216707, $\mathrm{p}=6,0 \times 10^{-10}$ ).

Консорціум SUNLIGHT 2018 року опублікував нові GWAS дані [19], де, крім описаних вище відомих варіантів, було визначено два нові варіанти в гені $S E C 23 A$ (Sec23 гомолог A, компонент поверхневого протеїнового комп-

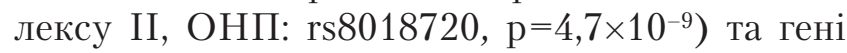
$A M D H D 1$ (аміногідролазовмісний домен $\mathrm{I}$, ОНП: rs10745742, p=1,9×10-14). Мутації в цих двох генах спричиняють краніо-лентикуло-сутуральну дисплазію, хворобу з мальформаціями лицьового черепа та скелета у зв'язку з порушеною секрецією колагену [20]. Важливо також, що вперше було виявлено варіанти в генах, не пов'язаних із метаболізмом вітаміну D.

Дані повногеномного секвенування, яке вивчало низькочастотні та рідкісні варіанти, показали новий ОНП у гені $C Y P 2 R 1$ (частота альтернативної алелі 2,5\%, rs117913124). Ефект даної алелі є в чотири рази вищим за попередньо визначені варіанти, а також незалежним від них. Особи, гетерозиготні за даною алеллю, мають вищий ризик дефіциту вітаміну D у 2,2 раза (95\% ДІ $\left.1,78-2,78, \mathrm{p}=1,26 \times 10^{-12}\right)$, а також в 1,4 раза (95\% ДІ $\left.1,19-164, \mathrm{p}=2,63 \times 10^{-5}\right)$ вищий ризик розвитку розсіяного склерозу. Ці дані є клінічно значущими [21].

Вищеописані генетичні варіанти дають підставу розцінювати фенотип циркулюючого рівня вітаміну D в організмі людини як ознаку 3 олігогенним впливом.

Вітамін D і цукровий діабет 1-го типу: генетичний аспект

Імовірно, що вітамін D є чинником захисту проти розвитку ЦД 1-го типу (ЦД1), оскільки він регулює імунну систему та розвиток автоімунних реакцій [22]. Встановлено, що поширеність ЦД збільшується зі збільшенням географічної широти [23]. Також концентрація вітаміну D у плазмі крові залежить від географічної широти, де проживають популяції людей, що є наслідком різного рівня інсоляції [24]. Результати досліджень різняться, проте встановлено, що приймання препаратів вітаміну D у дитинстві зменшує ризик розвитку ЦД1 [25, 26].

Попередні дослідження мають суттєві обмеження, оскільки рівень циркулюючого 
Огляди

$25(\mathrm{OH}) \mathrm{D}_{3}$ залежить не лише від надходження його з їжею. Попри те, що рівень вітаміну $25(\mathrm{OH}) \mathrm{D}_{3}$ нижчий в осіб із ЦД1 порівняно 3 контрольними суб'єктами [27], досі не має чітких даних, чи цей дефіцит починається перед або після встановлення діагнозу ЦД. У проспективних дослідженнях серед дітей із підвищеним ризиком ЦД1 рівень $25(\mathrm{OH}) \mathrm{D}_{3}$ не було пов'язано з розвитком автоімунних реакцій до острівців Лангерганса або наступним розвитком ЦД1 [28], проте дані досліджень серед осіб, в яких ЦД1 розвинувся в дорослому віці, показали, що перед встановленням діагнозу в них було зафіксовано нижчі рівні $25(\mathrm{OH}) \mathrm{D}_{3}[29,30]$.

Проведено низку генетичних досліджень, які вивчали вплив різних ОНП генів, відповідальних за метаболізм вітаміну D, на факт розвитку ЦД1. Так, 2004 року проведено масштабне дослідження, яке включало 3763 родини європейського походження, в яких є хворі на ЦД1. Метою був аналіз асоціацій 98 ОНП у гені $V D R$ із цим захворюванням. Результати показали відсутність асоціації ОНП у даному гені із ЦД1 [31].

У дослідженні типу випадок-контроль (родини, в яких є нащадки із ЦД1, і родини зі здоровими дітьми) вивчено зв'язок 13 ОНП у генах NADSYN1/DHCR7, VDR, GC і CYP27A1 iз розвитком діабету в дітей. Встановлено, що ОНП у гені $V D R$ мали різний розподіл у двох групах (rs1544410, $\mathrm{p}=0,007 ;$ rs731236, $\mathrm{p}=0,003$; $\mathrm{rs} 4516035, \mathrm{p}=0,015)$. Середня концентрація вітаміну D під час вагітності не різнилася в групах. Зроблено висновки, що певні варіанти в гені $V D R$ матері асоційовано з ризиком розвитку ЦД1 у дитини незалежно від генотипу за цими генами в нащадка. Можливо, вони впливають на внутрішньоутробне середовище і провокують раннє програмування щодо ЦД [32].

Нові дані американсько-європейського дослідження, яке включало 8676 дітей із підвищеним генетичним ризиком розвитку ЦД1 (за певними $H L A-D R-D Q$ генотипами), показало, що вищі рівні $25(\mathrm{OH}) \mathrm{D}_{3}$ у дитинстві асоційовано з нижчим ризиком розвитку автоімунних реакцій до острівців Лангерганса. Крім того, цю асоціацію було модифіковано однонуклеотидним поліморфізмом у гені $V D R$ (rs7975232) - вищі рівні 25(OH)D $\mathrm{D}_{3}$ у дитячому віці було асоційовано з нижчим рівнем авто- імунного ризику на підставі кількості мінорних алелей 0 (співвідношення шансів: 1,00; 95\% ДІ 0,93-1,07), 1 (співвідношення шансів: 0,92; 95\% ДІ 0,89-0,96), 2 (співвідношення шансів: 0,86; 95\% ДІ 0,80-0,92). Такі дані можуть свідчити, що рівень вітаміну D і генетичні варіанти його рецептора VDR можуть відігравати комбіновану роль у патогенезі розвитку автоімунних реакцій за ЦД1 [33].

Вплив вітаміну D i його генетичних детермінант на мінералізацію скелета у хворих на цукровий діабет 1-го типу

Щодо стану кісткової тканини та ï мінералізації в пацієнтів із ЦД1 показано, що МЩКТ (мінеральна щільність кісткової тканини) є суттєво меншою в пацієнтів із ЦД1 на рівнях як центрального, так і периферичного скелета [34]. Починаючи з дитинства та протягом усього життя хворі на ЦД1 були більш схильними до розвитку патологічних переломів [35]. Наші попередні дані також показали знижені рівні вітаміну D у дорослих пацієнтів із ЦД1 порівняно 3 такими в здорових осіб української когорти [36].

Наразі в наукових базах даних бракує інформації про зв'язок між рівнем вітаміну D, однонуклеотидними поліморфізмами в генах, які відповідають за його метаболізм, МЩКТ у пацієнтів із ЦД1, надто з точки зору вивчення цих компонентів у комплексі. Генетичні дослідження такого плану, які проводилися, зазвичай охоплювали когорти здорових дорослих осіб, дітей або жінок у постменопаузі [37, 38].

Цікавими є дослідження на тваринній моделі ЦД (стрептозоцин-індукований діабет у мишей), яке показало, що репарація дефекту кістки відбувалася достовірно уповільнено в мишей із діабетом, тоді як дефіцит вітаміну D у діабетичних і здорових мишей не справляв значущого впливу на час репарації дефекту кістки. Знижену МЩКТ у кортикальній і губчастій речовині кістки мишей було сильно потенційовано дефіцитом вітаміну D на рівні великогомілкової кістки в місці без дефекту. Тобто, дане дослідження показує, що дефіцит вітаміну D потенціює зниження МЩКТ у мишей із Цд, але не впливає на процес репарації кістки в стані ЦД [39].

Дослідження в когорті хворих на ЦД1 показало, що з урахуванням таких чинників, як вік, стать та IMT, ОНП BsmI (rs1544410), гено- 
тип BB у гені VDR асоційовано з нижчою середньою МЩКТ на рівні поперекового відділу хребта та стегнової кістки, ніж генотипи $\mathrm{Bb}$ i bb у пацієнтів із ЦД1 $(\mathrm{p}<0,05)$. Такі дані можуть свідчити про наявність невеликого впливу цього ОНП у гені $V D R$ на МЩКТ у пацієнтів із ЦД1 генетично гетерогенної популяції [40].

\section{Висновок}

Метаболізм вітаміну D є комплексним процесом, в який залучено низку ензимів, що кодуються генами $C Y P 2 R 1, C Y P 27 B 1, G C, C Y P 24 A 1$. Ген $V D R$ кодує рецептори до вітаміну $\mathrm{D}$, які $\mathrm{\epsilon}$ в багатьох тканинах. Дія вітаміну D відбувається через вплив на геном людини, в основному шляхом регуляції транскрипції інших генів. Успадковуваність циркулюючих рівнів вітаміну D коливається від 20\% до 85\% залежно від дизайну дослідження та пори року. У масштабних дослідженнях методом повногеномного скринінгу визначено ОНП, достовірно асоційовані $з$ рівнем $25(\mathrm{OH}) \mathrm{D}_{3}$ у сироватці крові. Наразі є досить велика кількість даних про наявність низького рівня вітаміну D і зниженої МЩКТ у пацієнтів із ЦД1. У наукових джерелах також є інформація про певні генетичні варіанти, асоційовані з такими результатами в цій когорті пацієнтів, проте бракує досліджень, які б порівнювали асоціації між поліморфізмами в різних генах, що відповідають саме за метаболізм вітаміну D, із МЩКТ у пацієнтів із ЦД1. Більшість досліджень, які вивчають таку асоціацію, проведено в когортах здорових людей, і зазвичай вони фокусуються лише на одному гені, найчастіше $V D R$ (ген рецептора до вітаміну D). Низькі рівні вітаміну D і знижена МЩКТ у пацієнтів із ЦД1, а також той факт, що ці показники взаємопов'язано, можуть мати генетичне підгрунтя, а з'ясування цього питання потребує подальших генетичних досліджень.

\section{Список використаної літератури}

1. Doppelt S. Vitamin D, rickets, and osteomalacia. Orthop Clin N Am. 1984;15(4):671-86.

2. Altieri B, Muscogiuri G, Barrea L, Mathieu C, Vallone CV, Mascitelli L, et al. Does vitamin D play a role in autoimmune endocrine disorders? A proof of concept. Rev Endocr Metab Dis. 2017;18(3):335-46.

3. Scaranti M, de Castro GJ, Hoff AO. Vitamin D and cancer: does it really matter? Curr opin oncol. 2016;28(3):205-9.

4. White JH. Vitamin D signaling, infectious diseases, and regulation of innate immunity. Infect immun. 2008;76(9):3837-43.
5. Van Belle TL, Vanherwegen AS, Feyaerts D, De Clercq P, Verstuyf A, Korf H, et al. 25-Dihydroxyvitamin D3 and its analog TX527 promote a stable regulatory $\mathrm{T}$ cell phenotype in T cells from type 1 diabetes patients. PloS one. 2014;9(10):109-94.

6. Prietl B, Treiber G, Pieber TR, Amrein K. Vitamin D and immune function. Nutrients. 2013;5(7):2502-21.

7. Bikle DD. Vitamin D metabolism, mechanism of action, and clinical applications. Chem biol. 2014;21(3):319-29.

8. Fraser D, Kodicek E. Unique biosynthesis by kidney of a biologically active vitamin D metabolite. Nature. 1970;228(5273):764.

9. Kliewer SA, Umesono K, Noonan DJ, Heyman RA, Evans RM. Convergence of 9-cis retinoic acid and peroxisome proliferator signalling pathways through heterodimer formation of their receptors. Nature. 1992;358(6389):771.

10. Moestrup SK, Verroust PJ. Megalin-and cubilin-mediated endocytosis of protein-bound vitamins, lipids, and hormones in polarized epithelia. Annu rev nutr. 2001;21(1):407-28.

11. Hunter D, De Lange M, Snieder H, MacGregor AJ, Swaminathan R, Thakker RV, Spector TD. Genetic contribution to bone metabolism, calcium excretion, and vitamin $\mathrm{D}$ and parathyroid hormone regulation. J Bone Miner Res. 2001;16(2):371-8.

12. Karohl C, Su S, Kumari M, Tangpricha V, Veledar E, Vaccarino V, Raggi P. Heritability and seasonal variability of vitamin D concentrations in male twins. The Am J Clin Nutr. 2010;92(6):1393-8.

13. Mills NT, Wright MJ, Henders AK, Eyles DW, Baune BT, McGrath JJ, et al. Heritability of transforming growth factor- $\beta 1$ and tumor necrosis factor-receptor type 1 expression and vitamin $\mathrm{D}$ levels in healthy adolescent twins. Twin Res Hum Genet. 2015;18(1):28-35.

14. Yu HJ, Kwon MJ, Woo HY, Park H. Analysis of 25-hydroxyvitamin D status according to age, gender, and seasonal variation. J Clin Lab Anal. 2016;30(6):905-11.

15. Dastani Z, Li R, Richards B. Genetic regulation of vitamin D levels. Calcified Tissue Int. 2013; 92(20):106-17.

16. Benjamin EJ, Dupuis J, Larson MG, Lunetta KL, Booth SL, Govindaraju DR, et al. Genome-wide association with select biomarker traits in the Framingham Heart Study. BMC Med Genet. 2007;8(1):1-11.

17. Wang TJ, Zhang F, Richards JB, Kestenbaum B, van Meurs JB, Berry D, et al. Common genetic determinants of vitamin D insufficiency: a genome-wide association study. The Lancet. 2010; 376(9736):180-8.

18. Ahn J, Yu K, Stolzenberg-Solomon R, Simon KC, McCullough ML, Gallicchio L, et al. Genome-wide association study of circulating vitamin D levels. Hum Mol Genet. 2010;19(13):2739-45.

19. Jiang X, O'Reilly PF, Aschard H, Hsu YH, Richards JB, Dupuis J, et al. Genome-wide association study in 79. 366 Europeanancestry individuals informs the genetic architecture of 25-hydroxyvitamin D level. Nat Commun. 2018;9(1):260.

20. Boyadjiev SA, Fromme JC, Ben J, Chong SS, Nauta C, Hur DJ, et al. Cranio-lenticulo-sutural dysplasia is caused by a SEC23A mutation leading to abnormal endoplasmic-reticulum-to-Golgi trafficking. Nat Gen. 2006;38(10):1192-7.

21. Manousaki D, Dudding T, Haworth S, Hsu YH, Liu CT, MedinaGómez C, et al. Low-frequency synonymous coding variation in CYP2R1 has large effects on vitamin D levels and risk of multiple sclerosis. Am J Hum Genet. 2017;101(2):227-38.

22. Rosen Y, Daich J, Soliman I, Brathwaite E, Shoenfeld Y. Vitamin D and autoimmunity. Scand J Rheumat. 2016;45(6):439-47.

23. Tuomilehto J. The emerging global epidemic of type 1 diabetes. Curr Diabetes Rep. 2013;13(6):795-804

24. Kimlin MG. Geographic location and vitamin D synthesis. Mol Aspects Med. 2008;29(6):453-61.

25. Dong JY, Zhang WG, Chen JJ, Zhang ZL, Han SF, Qin LQ. Vitamin D intake and risk of type 1 diabetes: a meta-analysis of observational studies. Nutrients. 2013;5(9):3551-62.

26. Hyppönen E, Läärä E, Reunanen A, Järvelin MR, Virtanen SM. Intake of vitamin D and risk of type 1 diabetes: a birth-cohort study. Lancet. 2001;358(9292):1500-3.

27. Feng R, Li Y, Li G, Li Z, Zhang Y, Li Q, Sun C. Lower serum $25(\mathrm{OH}) \mathrm{D}$ concentrations in type 1 diabetes: a meta-analysis. Diabetes Res Clin Pr. 2015;108(3):71-7.

28. Simpson M, Brady H, Yin X, Seifert J, Barriga K, Hoffman M, et al. No association of vitamin D intake or 25-hydroxyvitamin D levels 
Огляди

in childhood with risk of islet autoimmunity and type 1 diabetes: the Diabetes Autoimmunity Study in the Young (DAISY). Diabetologia. 2011;54(11):2779-88.

29. Munger KL, Levin LI, Massa J, Horst R, Orban T, Ascherio A. Preclinical serum 25-hydroxyvitamin D levels and risk of type 1 diabetes in a cohort of US military personnel. Am J Epidemiol. 2013;177(5):411-9.

30. Gorham ED, Garland CF, Burgi AA, Mohr SB, Zeng K, Hofflich H, et al. Lower prediagnostic serum 25-hydroxyvitamin et al., Lower prediagnostic serum 25-hydroxyvitamin D concentration is associated with higher risk of insulin-requiring diabetes: a nested case-control study. Diabetologia. 2012;55(12):3224-7.

31. Nejentsev S, Cooper JD, Godfrey L, Howson JM, Rance H, Nutland S, et al. Analysis of the vitamin D receptor gene sequence variants in type 1 diabetes. Diabetes. 2004;53(10):2709-12.

32. Miettinen ME, Smart MC, Kinnunen L, Mathews C, Harjutsalo V, Surcel HM, etal. Maternal VDR variants ratherthan 25-hydroxyvitamin D concentration during early pregnancy are associated with type 1 diabetes in the offspring. Diabetologia. 2015;58(10):2278-83.

33. Norris JM, Lee HS, Frederiksen B, Erlund I, Uusitalo U, Yang J, Lernmark $\AA$, et al. Plasma 25-hydroxyvitamin D concentration and risk of islet autoimmunity. Diabetes. 2018;67(1):146-54.

34. Shah VN, Harrall KK, Shah CS, Gallo TL, Joshee P, SnellBergeon JK, Kohrt WM. Bone mineral density at femoral neck and lumbar spine in adults with type 1 diabetes: a meta-analysis and review of the literature. Osteoporosis Int. 2017; 28(9):2601-10.

35. Weber DR, Haynes K, Leonard MB, Willi SM, Denburg MR. Type 1 diabetes is associated with an increased risk of fracture across the life span: a population-based cohort study using The Health Improvement Network (THIN). Diabetes Care. 2015;38(10):1913-20.

36. Шубелка ХM, Олексик ОТ, Ганич ТН. Стан забезпечення вітаміном D, рівень кальцію, магнію і паратгормону у хворих на цукровий діабет. Міжнародний ендокринологічний журнал. 2017;13(8): 570-73. (Shchubelka KhM, Oleksyk OT, Hanych TN. Vitamin D status, calcium, magnesium and parathyroid hormone levels in patients with diabetes mellitus. Int J Endocrinol. 2017;13(8):570-73).

37. Li S-S, Gao L-H, Zhang X-Y, He J-W, Fu W-Z, Liu Y-J, et al. Genetically low vitamin D levels, bone mineral density, and bone metabolism markers: a Mendelian randomisation study. Scientific reports. 2016;6:33202.

38. Bao L, Chen M, Lei Y, Zhou Z, Shen H, Le F. Association between vitamin $\mathrm{D}$ receptor BsmI polymorphism and bone mineral density in pediatric patients: A meta-analysis and systematic review of observational studies. Medicine (Baltimore). 2017;96(17):e6718.

39. Mao L, Tamura Y, Kawao N, Okada K, Yano M, Okumoto K, Kaji H. Influence of diabetic state and vitamin D deficiency on bone repair in female mice. Bone. 2014;61:102-8.

40. Hauache OM, Lazaretti-Castro M, Andreoni S, Gimeno SG, Brandão C, Ramalho $\mathrm{AC}$, et al. Vitamin $\mathrm{D}$ receptor gene polymorphism: correlation with bone mineral density in a Brazilian population with insulin-dependent diabetes mellitus. Osteoporosis Int. 1998;8(3):204-10.

(Надійшла до редакиії 07.11.2019 р.)

\section{Витамин D в генетическом аспекте и его роль при сахарном диабете 1-го типа}

\section{Х.М. Щубелка ${ }^{1,2}$, О.Т. Олексик', Т.Х. Олексик², Я.С. Гасинець ${ }^{1}$}

${ }^{1}$ ДВНЗ «Ужгородский национальный университет»

${ }^{2}$ Oakland University

Резюме. Витамин D участвует в различных биологических процессах, включая костный метаболизм, модуляцию иммунного от- вета и регуляцию пролиферации и дифференции клеток. Дефицит витамина D связывают с возникновением таких нескелетных заболеваний, как сахарный диабет 1-го и 2-го типов, рак, сердечно-сосудистые заболевания, что подтверждает плейотропный характер биологического действия витамина D. Генетические исследования дают возможности изучить генетически-молекулярные механизмы воздействия на циркулирующие уровни витамина D. Вариативные участки ДНК, которые часто встречаются в популяции - однонуклеотидные полиморфизмы (ОНП, SNP) - могут влиять на метаболизм витамина D, а также модулировать его действие при развитии сахарного диабета 1-го типа. В обзоре приведены данные литературы о молекулярных механизмах действия витамина D, а также генов, кодирующих ферменты, ответственные за его метаболизм, рассмотрены самые масштабные генетические исследования различного типа в человеческих популяциях, целью которых было изучение наследственности циркулирующих уровней витамина D, влияние этих генетических детерминант на развитие сахарного диабета 1-го типа.

Ключевые слова: витамин D, сахарный диабет, генетические исследования.

\section{Vitamin $D$ in the genetic aspect, the role in type 1 diabetes mellitus}

\section{K.M. Shchubelka ${ }^{1,2}$, O.T. Oleksyk' ${ }^{1}$, T.K. Oleksyk ${ }^{2}$, Y.S. Hasynets ${ }^{1}$}

'SU «Uzhhorod National University»

${ }^{2}$ Oakland University

Abstract. Vitamin D is involved in a variety of biological processes, including bone metabolism, immune response regulation, it impacts cell proliferation and differentiation. Vitamin D deficiency is associated with such non-skeletal diseases as diabetes mellitus type 1 and type 2, cancer, cardiovascular diseases, which confirms the pleiotropic nature of the biological function of vitamin D. Genetic studies provide great opportunities to study the genetic and molecular which define circulating levels of vitamin D. Variable DNA regions that are common in the populations are called single-nucleotide polymorphisms (SNPs) and can have an effect on the metabolism of vitamin D, as well as modulate the action of vitamin $\mathrm{D}$ in the development of type 1 diabetes mellitus in humans. The article provides the literature overview on the molecular mechanisms of action of vitamin D, as well as the genes encoding enzymes responsible for the metabolism of vitamin D. Also it reviews the most extensive genetic studies in human, the purpose of which was to study the inheritance of circulating levels of vitamin $D$, the influence of these genetic determinants on the development of type 1 diabetes mellitus.

Keywords: vitamin D, diabetes mellitus, genetic studies. 